\title{
COMPARISON OF THE CHEMICAL COMPOSITION OF WHEY CHEESES: URDA AND RICOTTA
}

\author{
Snežana Paskaš ${ }^{1}$, Jelena Miočinović2 , Mila Savić ${ }^{3}$, Goran Ješić ${ }^{4}$, \\ Mladen Rašeta ${ }^{5}$, Zsolt Becskei ${ }^{3}$ \\ 'Department of Animal Science, Faculty of Agriculture, University of Novi Sad, \\ Trg Dositeja Obradovića 8, 21000 Novi Sad, Serbia \\ ${ }^{2}$ Department of Animal Science of Food Technology, Faculty of Agriculture, \\ University of Belgrade, Nemanjina 6, 11000 Belgrade-Zemun, Serbia \\ ${ }^{3}$ Department of Animal Breeding and Genetics, Faculty of Veterinary Medicine, \\ University of Belgrade, Bulevar Oslobodjenja 18, 11000 Belgrade, Serbia \\ ${ }^{4}$ National Assembly of the Republic of Serbia, Trg Nikole Pašića 13, 11000 Belgrade, Serbia \\ ${ }^{5}$ Institute of Meat Hygiene and Technology, Kaćanskog 13, 11000 Belgrade, Serbia
}

Received 21 September 2018; Received in revised form 12 July 2019; Accepted 12 July 2019

\begin{abstract}
This study was conducted to evaluate the nutritional quality of two types of cheese prepared from bovine whey: Urda and Ricotta. Cheeses were examined for chemical parameters and their amino acids profile was determined. The results revealed that the chemical composition of the observed whey cheeses was highly significantly different $(p<0.01)$ from each other. The amounts of dry matter, fat, protein, lactose, ash and salt were higher in Ricotta compared with Urda cheese samples. On the other hand, Urda contained more moisture, fat on a dry matter basis and moisture on a fat-free basis $(79.59 \%, 27.50 \%$, $84.27 \%$ versus $69.82 \%, 21.02 \%, 74.56 \%$, respectively). Especially higher yield, salt in moisture content and energy values were observed in Ricotta cheese $(5.93 \%, 3.12 \%, 145.99 \mathrm{Kcal} / 100 \mathrm{~g}$ versus $4.39 \%, 2.40 \%, 108.97 \mathrm{Kcal} / 100 \mathrm{~g}$; Ricotta and Urda, respectively). Whey cheeses are a particularly good source of amino acids containing approximately - Ricotta: leucine $(1.60 \mathrm{~g} / 100 \mathrm{~g})$, lysine $(1.17 \mathrm{~g} / 100 \mathrm{~g})$, phenylalanine $(0.78 \mathrm{~g} / 100 \mathrm{~g})$ and followed by threonine $(0.77 \mathrm{~g} / 100 \mathrm{~g})$, while Urda contained leucine $(0.80 \mathrm{~g} / 100 \mathrm{~g})$, lysine $(0.45 \mathrm{~g} / 100 \mathrm{~g})$, threonine $(0.68 \mathrm{~g} / 100 \mathrm{~g})$ and phenylalanine $(0.31 \mathrm{~g} / 100 \mathrm{~g})$. Both cheese varieties contained glutamic and aspartic acid as the predominant non-essential amino acids (Ricotta: $3.91 \mathrm{~g} / 100 \mathrm{~g}$ and $1.68 \mathrm{~g} / 100 \mathrm{~g}$ versus Urda: $1.65 \mathrm{~g} / 100 \mathrm{~g}$ and $0.80 \mathrm{~g} / 100 \mathrm{~g}$, respectively). Generally, from a nutritional point of view, the investigated whey cheeses could be considered as cheeses with low salt and fat content, as well as cheeses particularly abundant in branched chain amino acids (leucine, isoleucine and valine). These results also emphasize their advantages as products that present a cost-effective way of dealing with whey as waste material.
\end{abstract}

Key words: Urda, Ricotta, chemical composition, amino acids profile, nutritional value

\section{INTRODUCTION}

Whey, which contains about $50 \%$ of the total solids of milk and was regarded as waste until recently, can serve as the raw material for the

Corresponding author: Dr. Zsolt Becskei, $\mathrm{PhD}$

E-mail address: beckeizolt@gmail.com

Present address: Department of Animal Breeding and Genetics,

Faculty of Veterinary Medicine, University of Belgrade,

Bulevar Oslobodjenja 18, 11000 Belgrade, Serbia

Phone: +381 659911101

Copyright: (C) 2019 Paskaš S. This is an open-access article published under the terms of the Creative Commons Attribution License which permits unrestricted use, distribution, and reproduction in any medium, provided the original author and source are credited.

Competing Interests: The authors have declared that no competing interests exist.

Available Online First: 31 August 2019

Published on: 15 October 2019

https://doi.org/10.2478/macvetrev-2019-0020 production of a wide range of food products and food ingredients (1). Thanks to its components, whey also represents a valuable product as a material for cheese production (2). Cheese made of whey is substantially different in its composition and in particular in the content of proteins which make lactoalbumin and lactoglobulin, unlike cheese proteins consisting of casein and paracasein. Furthermore, they are significantly different from one another in terms of chemical composition, which is mainly due to variations in the source and type of whey, as well as to the processing practices followed (3). The composition of cheese has a marked influence on all aspects of its quality (4). In general, whey cheeses have such 
a composition and properties which give them justification for their separation as a special group of dairy products (5). Ricotta is mostly known as unripened soft whey cheese that originated from Italy. Traditionally, the starting material used for the manufacture of Ricotta cheese was whey collected during Mozzarella cheese production (6). The texture of Ricotta is soft and creamy and with a pleasant taste of cooked milk (7). At present, Ricotta cheese can be made from almost any type of sweet whey $(\mathrm{pH} \geq 6)(6)$ and it is increasingly produced in industrial conditions (8). Moreover, Urda cheese production in industrial conditions can occupy an important place in assortment range of milk products, because of its high biological value and flavour qualities (9). Urda is known as an albumin rich cheese obtained by heat-induced coagulation of whey proteins. It belongs to the soft cheese group and is mostly used as fresh cheese (10). Milk, cream or other raw materials of milk origin can be added to the whey cheese production, before or after concentration or coagulation. This increases the nutritive value of the whey cheese, the quantity of protein and the quantity of essential amino acids in the protein (5). Kaminarides et al. (11) reported that the addition of skimmed milk to whey in the production of traditional Greek whey cheese (Myzithra) resulted in a new dietary product, with good quality, harder texture and higher levels of ash. A number of previous studies have been performed to compare the quality and chemical composition of different whey cheeses varieties, but the amino acids profile may be also a useful criterion in the determination of their value (6). The nutritional value of whey cheese is mainly determined by its high-quality proteins, which are easily digestible and have a high level of utilization (12). Whey proteins contain essential and nonessential amino acids in higher concentrations as compared to vegetable protein sources (13). Besides that, whey proteins are a great source of branched chain amino acids (BCAAs) (leucine, isoleucine and valine), which are particularly useful for athletes and sarcopenic conditions (2). BCAAs are the only amino acids not degraded in the liver (14). Most cheeses contain significant amounts of fat, and nutritionists emphasize that cheeses with higher protein content and less fat are more desirable for human nutrition (15). Particularly, low-fat dairy products do not increase the risk of cardiovascular disease (16). Cho et al. (17) reported that the consumption of Ricotta cheese in amounts of more than $25 \mathrm{mg}$ per day could be protective against colon cancer. In addition, carbohydrates which are found in the form of lactose are generally considered to be of low carcinogenicity (18). Moreover, Ricotta and Urda cheese as low-calorie dairy products are important in the diet of elderly people. In the future, finding ways to incorporate protein-rich foods that are not high in calories, fat and cholesterol into the diet and then translating this into increased wholebody lean mass can be challenging (19).

Due to the growing popularity of Ricotta and Urda cheese in Serbia and as this topic was the examined scantily, the aim of the study was to evaluate the chemical composition of two whey types of cheese, Urda and Ricotta, produced in industrial conditions. Furthermore, the amino acids profiles of the investigated cheeses were determined. Based on this data, we made an assessment and a comparison of their chemical and amino acids characteristics.

\section{MATERIAL AND METHODS}

\section{Production of semi-hard cheese}

For the production of semi-hard (Kashkaval) cheese, pasteurized and standardized bovine milk was used. The production technology of semi-hard cheese was described by Popović-Vranješ (5).

\section{Chemical composition of whey}

Obtained whey in the process of production of semi-hard cheese had an average value of dry matter of $7.01 \%$, protein $0.76 \%$, fat $0.41 \%$, lactose $4.84 \%$ and ash $0.60 \%$.

\section{Whey cheese production}

Samples of Urda and Ricotta cheese were produced from sweet whey in a local cheese plant. Manufacture of whey cheese is based on the principle that whey proteins will precipitate when slightly acidified $(\mathrm{pH}=6)$ and then heated to high temperatures $\left(80-85^{\circ} \mathrm{C}\right)(3)$. An acidification agent, which is applied in the form of an aqueous solution of citric acid, is needed to help the denaturation and final precipitation of the whey proteins (20).

\section{Manufacture of Urda}

Manufacturing of Urda albumin cheese, according to the industrial production technology (5), was provided using bovine whey which was heated gradually under continuous stirring to $85^{\circ} \mathrm{C}$. At this point, monohydrate citric acid (E-330) was added to the whey (in the amount of $(0.05-0.1 \%)$ as a water solution (2.5\%)). It decreased the $\mathrm{pH}$ value of 
the starting material to approximately 5.42 (Table 1 ). As the temperature reached a value above of $85^{\circ} \mathrm{C}$, the heater was turned off and the whey stood still around 30 minutes until a thick layer of curd was formed on the surface. When the curd formed, it was transferred to the thick strainer for drainage during the next 6-7 hours, at a temperature of $19-21^{\circ} \mathrm{C}$, and self-pressing. After completion of the squeeze, curd was salted (in an amount: $1-2 \%$, at a temperature of $10-12^{\circ} \mathrm{C}$ ). Finally, Urda was packed in plastic cups (250g to $500 \mathrm{~g}$ ), using a thermowelding package and products were shifted to the refrigerator and cooled $\left(1-8^{\circ} \mathrm{C}\right)$. Urda is usually sold as fresh cheese and stored up to 3 to 4 days.

\section{Manufacture of Ricotta}

Manufacturing of Ricotta cheese, according to the industrial production technology (5), was provided using whey which was slowly heated by injecting steam with low pressure. Whole milk was added at a temperature of $60-70^{\circ} \mathrm{C}$ (in the amount of $10 \%$, the milk also had been previously heated to $40-50^{\circ} \mathrm{C}$ ). The average chemical composition of the milk was: $11.99 \%$ dry matter, $3.38 \%$ fat, $3.34 \%$ protein, lactose $4.25 \%, 1.02 \%$ ash and a $\mathrm{pH}$ value of 7.03. The mixture after that was heated gradually under continuous stirring up to $80-90^{\circ} \mathrm{C}$, for $15 \mathrm{~min}$. At this stage, monohydrate citric acid (E-330) (in an amount of $0.02-0.05 \%$ ) was added as a water solution (1.5-2\%). The citric acid reduced the $\mathrm{pH}$ value to approximately 5.44 (Table 1). Gentle stirring was provided until small curd particles of the coagulated whey proteins appeared. After that, the insertion of steam was slowly decreased, the mixture standing still until the curd became firm. The curd then was transferred to into perforated moulds and mass drainages for 10 minutes. Protein mass was self-pressed at a temperature of $15-20^{\circ} \mathrm{C}$, during the next 20 minutes. Salting of the cheese was carried out at a temperature of $10-12^{\circ} \mathrm{C}$, then it was left in the mould, cooling at low temperatures $\left(4-10^{\circ} \mathrm{C}\right)$, for $6-12$ hours. Ricotta is packed in hermetic plastic cups $(250 \mathrm{~g}$ to $500 \mathrm{~g})$. It could be sold as fresh or stored at refrigerator temperature $\left(1-8^{\circ} \mathrm{C}\right)$ for up to 30 days. The samples were analyzed fresh.

\section{Collecting samples and physical analyses}

Samples were collected during a one month period, arranged at the same time intervals. During the production process, the active acidity of whey and cheeses were measured with a $\mathrm{pH}$ meter (WTW, type ino Lab pH 720) (AOAC 981.12) (21). The obtained cheeses were weighed immediately after production, using a digital weight scale (Sartorius,
TE2145). The yield of the cheese was calculated as follows: yield = weight of cheese $\mathrm{x} 100 /$ weight of whey (5).

\section{Chemical analysis}

The chemical compositions of 15 samples of Urda and Ricotta from different production batches were determined after their production (total, $n=30$ ). About $100 \mathrm{~g}$ of cheese was taken from various parts of the cheese mass for analyzing. The proximate analysis of the cheese and whey samples was carried out following the standard methods of the Association of Official Analytical Chemists (22), unless otherwise stated. The total solids were determined with a standard method of measuring weight loss after drying (AOAC 926.08-1927). For determination of protein content was used Kjeldahl-Van Slyke method for the determination of total N (AOAC 2001.14) with a Kjeltec Auto Analyzer (Model 2400, Tecator, Hoganas, Sweden) and converting with a multiplication factor of 6.38. The fat content was determined according to Van Gulik (23), the lactose by gravimetry method (AOAC, 930.28) (24) and ash by dry ashing at $550^{\circ} \mathrm{C}$ (AOAC 935.42). The $\mathrm{NaCl}$ content was determined by colourimetric titration with a chloride analyzer (model 926, Corning, Medfield, MA, USA). The chloride analyzer is intended for general laboratory use and is calibrated in ppm (mg/l) chloride. A simple factor switch offers the immediate conversion of chloride content into $\mathrm{mg} \%(\mathrm{NaCl})$ of the original sample. The factor is obtained using the atomic weight of $\mathrm{Na}(22.98)$ and $\mathrm{Cl}$ (35.45). The molecular weight of $\mathrm{NaCl}$ is 58.43 and to convert from $\mathrm{Cl}$ to $\mathrm{NaCl}$ we multiply by $58.5 / 35.45=1.6482$. The obtained reading for chloride is converted using this factor and after that multiplied by the 100:1 dilution factor $=3300 \mathrm{mg} \%$ or $3.3 \%$.

Fat on a dry matter basis (FDM, \%) was calculated as fat/(100-moisture $) \times 100$, and moisture on a fat-free basis (MFFB, \%) was estimated as moisture $/(100$-fat $) \times 100$. Calculations for salt in moisture $(\mathrm{S} / \mathrm{M}, \%)$ were performed using the equation: cheese salt $(\%) \times 100 /(100$-cheese total solids, \%) (5). The energy value was determined according to Popović-Vranješ (5).

\section{Amino acids profile}

The amino acids profile of whey cheeses was performed following the protocol of Henderson (25). Three replicates of both types of cheese (Ricotta, $\mathrm{n} 1=3$; Urda, $\mathrm{n} 2=3$ ) were analyzed for the content of amino acids after acid hydrolysis, using the HPLC method (High-Performance Liquid Chromatograph 
Chromaster, Zorbax Eclipse-AAA column $(4.6 \times$ $250,5 \mu \mathrm{m}$ ) with DAD-3000 (diode array detector).

\section{Statistical analysis}

Based on the obtained analytical results, the parameters of $\mathrm{pH}$ values, yield and content of the analyzed components in the cheese samples were compared. The obtained results of cheeses were analyzed using Statistica 9.0 and significant statistical differences were determined using onetailed t-test (for two samples). The significance level was set at $\mathrm{p}<0.05$ and $\mathrm{p}<0.01$. In addition, descriptive statistics were applied and the results were presented as the arithmetic mean, range and coefficient of variation.

\section{RESULTS}

\section{$p H$ values of whey and cheeses}

Samples of Urda and Ricotta cheese were produced from whey with similar initial $\mathrm{pH}$ values, which ranged from 6.31 to 6.53 and 6.30 to 6.48 , respectively (Table 1). The significant differences in $\mathrm{pH}$ values during cheese production between investigated cheeses were not established. The final Ricotta during packaging had a $\mathrm{pH}$ value in the range of 5.65-6.05, while Urda varied between pH 5.60-6.24 (Table 1).

\section{Chemical composition}

Results related to the chemical composition of whey cheeses are presented in Tables 2 and 3.
Investigated cheeses showed a highly significant difference $(\mathrm{p}<0.01)$ in their chemical composition. In particular, Urda possessed a higher percentage of moisture, while Ricotta samples were more compact and contained significantly higher protein content $(79.59 \%$ vs. $69.82 \%$, and $10.66 \%$ vs. $16.88 \%$, respectively). The range between minimal and maximal assessed values for protein and fat content of both types of cheese was very high (Ricotta, $14.88-18.72 \%$ and $4.25-7.58 \%$ vs. Urda, 8.94-12.71\% and 4.00-7.00\%, respectively). At the same time, coefficients of variation of Urda varied more in regard of dry matter $(7.99 \%$ vs. $5.50 \%)$, protein $(9.66 \%$ vs. $6.28 \%)$ and lactose (14.29\% vs. 8.39\%), while values for fat content were within narrow limits (16.87\% vs. 16.35\%, respectively).

The milk addition in Ricotta cheese production also resulted in higher yields of cheese and higher energy value of Ricotta compared to Urda cheese $(\mathrm{p}<0.01)$. Estimated mean values amounted to $145.99 \mathrm{kcal} / 100 \mathrm{~g} v s .108 .97 \mathrm{kcal} / 100 \mathrm{~g}$ (Ricotta and Urda, respectively) (Table 3). Likewise, in the case of other parameters, the level of salt was significantly greater in Ricotta cheese $(2.18 \%$ vs. $1.95 \%$, respectively) $(\mathrm{p}<0.01)$. Considering these parameters and the levels of $\mathrm{S} / \mathrm{M}$ together with the $\mathrm{pH}$ indicates whether proper procedures were used to manufacture these specific cheese varieties. It was observed that both types of cheese varied widely in terms of ash content (14.14\% vs. 15.21\%, Urda and Ricotta, respectively).

Table 1. $\mathrm{pH}$ values of Urda and Ricotta whey cheese during the production process

\begin{tabular}{|c|c|c|c|c|c|c|}
\hline \multirow{2}{*}{ Parameters } & \multicolumn{3}{|c|}{ URDA } & \multicolumn{3}{|c|}{ RICOTTA } \\
\hline & $\mathbf{X}_{\min }-\mathbf{X}_{\max }$ & $\bar{x} \pm \mathbf{S d}$ & cv $(\%)$ & $\mathbf{X}_{\min }-\mathbf{X}_{\max }$ & $\bar{x} \pm \mathbf{S d}$ & cv $(\%)$ \\
\hline pH of whey, input & $6.31-6.53$ & $6.46 \pm 0.05$ & 0.77 & $6.30-6.48$ & $6.41 \pm 0.05$ & 0.78 \\
\hline $\begin{array}{l}\text { pH of whey, adjusted with citric } \\
\text { acid }\end{array}$ & $5.13-5.66$ & $5.42 \pm 0.17$ & 3.14 & $5.19-5.67$ & $5.44 \pm 0.12$ & 2.21 \\
\hline $\begin{array}{l}\text { pH value during draining of the } \\
\text { curd }\end{array}$ & $5.34-5.89$ & $5.62 \pm 0.16$ & 2.85 & $5.21-5.77$ & $5.67 \pm 0.14$ & 2.47 \\
\hline pH value after the salting & $5.58-6.01$ & $5.77 \pm 0.12$ & 2.08 & $5.61-5.88$ & $5.70 \pm 0.08$ & 1.40 \\
\hline $\begin{array}{l}\text { pH value of the cheese during } \\
\text { packaging }\end{array}$ & $5.60-6.24$ & $5.97 \pm 0.16$ & 2.68 & $5.65-6.05$ & $5.85 \pm 0.12$ & 2.05 \\
\hline
\end{tabular}

$\bar{x}$-arithmetic mean; Sd-standard deviation; cv (\%)-coefficient of variation; minimal X (min) and maximal X (max) values of variables 
Table 2. The chemical composition of Urda and Ricotta cheese

\begin{tabular}{|c|c|c|c|c|c|c|c|c|c|c|}
\hline \multirow[b]{2}{*}{ Samples } & \multicolumn{5}{|c|}{ URDA } & \multicolumn{5}{|c|}{ RICOTTA } \\
\hline & $\begin{array}{c}\text { Moisture } \\
\text { (\%) }\end{array}$ & $\begin{array}{l}\text { DM } \\
(\%)\end{array}$ & $\begin{array}{l}\text { Fat } \\
(\%)\end{array}$ & $\begin{array}{c}\text { Protein } \\
(\%)\end{array}$ & $\begin{array}{c}\text { Lactose } \\
(\%)\end{array}$ & $\begin{array}{c}\text { Moisture } \\
\text { (\%) }\end{array}$ & $\begin{array}{l}\text { DM } \\
(\%)\end{array}$ & $\begin{array}{l}\text { Fat } \\
(\%)\end{array}$ & $\begin{array}{c}\text { Protein } \\
(\%)\end{array}$ & $\begin{array}{c}\text { Lactose } \\
(\%)\end{array}$ \\
\hline 1 & 81.80 & 18.20 & 5.0 & 9.42 & 2.58 & 71.08 & 28.92 & 4.25 & 17.43 & 4.62 \\
\hline 2 & 78.08 & 21.92 & 6.0 & 10.98 & 3.79 & 69.20 & 30.80 & 5.43 & 18.72 & 4.63 \\
\hline 3 & 80.24 & 19.76 & 4.5 & 10.97 & 3.31 & 72.99 & 27.01 & 5.26 & 14.88 & 3.97 \\
\hline 4 & 78.36 & 21.64 & 7.0 & 10.32 & 3.17 & 69.01 & 30.99 & 6.73 & 17.32 & 3.93 \\
\hline 5 & 78.21 & 21.79 & 7.0 & 10.24 & 3.54 & 70.72 & 29.28 & 7.14 & 15.94 & 3.85 \\
\hline 6 & 80.56 & 19.44 & 6.5 & 9.58 & 2.43 & 68.50 & 31.50 & 7.50 & 16.34 & 4.98 \\
\hline 7 & 78.85 & 21.15 & 6.0 & 11.21 & 3.13 & 68.49 & 31.51 & 7.24 & 16.97 & 4.31 \\
\hline 8 & 78.81 & 21.19 & 5.5 & 11.03 & 3.87 & 67.95 & 32.05 & 6.50 & 18.21 & 4.20 \\
\hline 9 & 82.21 & 17.79 & 4.5 & 8.94 & 3.48 & 67.46 & 32.54 & 7.32 & 18.03 & 3.99 \\
\hline 10 & 81.46 & 18.54 & 4.0 & 9.99 & 3.35 & 69.84 & 30.16 & 6.54 & 17.41 & 3.88 \\
\hline 11 & 79.62 & 20.38 & 5.5 & 10.93 & 3.18 & 67.95 & 32.05 & 7.58 & 17.37 & 4.54 \\
\hline 12 & 81.39 & 18.61 & 5.0 & 9.98 & 2.67 & 70.60 & 29.40 & 5.10 & 16.89 & 4.31 \\
\hline 13 & 77.98 & 22.02 & 6.5 & 12.31 & 2.28 & 70.16 & 29.84 & 6.54 & 16.31 & 4.68 \\
\hline 14 & 79.43 & 20.57 & 5.0 & 11.27 & 3.32 & 72.43 & 27.57 & 5.25 & 15.45 & 4.55 \\
\hline 15 & 76.81 & 23.19 & 6.5 & 12.71 & 3.11 & 70.94 & 29.06 & 7.03 & 15.97 & 3.97 \\
\hline $\bar{x}$ & 79.59 & 20.41 & 5.63 & 10.66 & 3.15 & $69.82^{b}$ & $30.18^{b}$ & $6.36^{b}$ & $16.88^{b}$ & $4.29^{\mathrm{b}}$ \\
\hline Sd & 1.63 & 1.63 & 0.95 & 1.03 & 0.47 & 1.66 & 1.66 & 1.04 & 1.06 & 0.36 \\
\hline $\operatorname{cv}(\%)$ & 2.05 & 7.99 & 16.87 & 9.66 & 14.29 & 2.34 & 5.50 & 16.35 & 6.28 & 8.39 \\
\hline
\end{tabular}

DM-dry matter; $\bar{x}$-arithmetic mean; Sd-standard deviation; cv (\%)-coefficient of variation

${ }^{\mathrm{b}}$ Statistically significant difference $(\mathrm{p}<0.01)$ existed between Ricotta and the corresponding parameters obtained for Urda cheese

Table 3. Results of the chemical composition of the Urda and Ricotta

\begin{tabular}{|c|c|c|c|c|c|c|c|c|c|c|c|c|}
\hline \multirow[b]{2}{*}{ Samples } & \multicolumn{6}{|c|}{ URDA } & \multicolumn{6}{|c|}{ RICOTTA } \\
\hline & $\begin{array}{l}\text { Ash } \\
\text { (\%) }\end{array}$ & $\begin{array}{c}\mathrm{NaCl} \\
(\%)\end{array}$ & $\begin{array}{l}\text { S/M } \\
(\%)\end{array}$ & $\begin{array}{l}\text { Yield } \\
(\%)\end{array}$ & $\begin{array}{c}E V \\
(K J / 100 g)\end{array}$ & $\begin{array}{c}\text { EV } \\
\text { Kcal/100g }\end{array}$ & $\begin{array}{l}\text { Ash } \\
\text { (\%) }\end{array}$ & $\begin{array}{c}\mathrm{NaCl} \\
(\%)\end{array}$ & $\begin{array}{l}\text { S/M } \\
(\%)\end{array}$ & $\begin{array}{c}\text { Yield } \\
(\%)\end{array}$ & $\begin{array}{c}\text { EV } \\
\text { KJ/100g }\end{array}$ & $\begin{array}{c}\text { EV } \\
\text { Kcal/100g }\end{array}$ \\
\hline 1 & 0.91 & 1.90 & 2.32 & 3.90 & 400.35 & 95.37 & 2.62 & 2.13 & 2.99 & 5.93 & 543.52 & 129.93 \\
\hline 2 & 1.21 & 1.89 & 2.42 & 4.45 & 486.77 & 116.36 & 2.02 & 1.98 & 2.86 & 6.38 & 611.73 & 146.18 \\
\hline 3 & 0.98 & 1.87 & 2.33 & 4.70 & 419.99 & 100.40 & 2.89 & 1.94 & 2.66 & 6.45 & 527.94 & 126.21 \\
\hline 4 & 1.15 & 1.99 & 2.54 & 4.47 & 503.73 & 120.41 & 3.01 & 2.04 & 2.96 & 6.23 & 627.33 & 149.96 \\
\hline 5 & 1.01 & 2.01 & 2.57 & 4.84 & 508.70 & 121.59 & 2.35 & 2.36 & 3.34 & 5.55 & 617.22 & 147.54 \\
\hline 6 & 0.93 & 2.04 & 2.98 & 4.47 & 458.88 & 109.69 & 2.68 & 2.28 & 3.33 & 5.98 & 657.47 & 157.16 \\
\hline 7 & 0.81 & 2.07 & 2.62 & 4.32 & 479.39 & 114.59 & 2.99 & 2.36 & 3.43 & 5.60 & 646.67 & 154.58 \\
\hline 8 & 0.79 & 1.94 & 2.46 & 4.60 & 469.53 & 112.24 & 3.14 & 2.35 & 3.47 & 6.33 & 637.25 & 152.33 \\
\hline 9 & 0.87 & 1,92 & 2.34 & 4.68 & 388.09 & 92.77 & 3.21 & 2.02 & 2.99 & 6.12 & 662.46 & 158.36 \\
\hline 10 & 1.20 & 1.86 & 2.28 & 4.60 & 384.42 & 91.89 & 2.33 & 2.12 & 3.04 & 6.25 & 619.59 & 148.11 \\
\hline 11 & 1.19 & 1.88 & 2.36 & 4.27 & 455.99 & 108.99 & 2.56 & 2.31 & 3.40 & 5.90 & 670.69 & 160.32 \\
\hline 12 & 0.96 & 1.98 & 2.43 & 4.35 & 411.50 & 98.37 & 3.10 & 1.98 & 2.80 & 5.33 & 568.19 & 134.35 \\
\hline 13 & 0.93 & 2.01 & 2.58 & 4.12 & 503.14 & 120.27 & 2.31 & 2.19 & 3.12 & 4.60 & 614.45 & 146.88 \\
\hline 14 & 0.98 & 1.91 & 2.40 & 4.01 & 444.77 & 106.32 & 2.22 & 2.14 & 2.95 & 5.64 & 547.28 & 130.82 \\
\hline 15 & 0.87 & 1.98 & 2.58 & 4.00 & 524.24 & 125.31 & 2.09 & 2.50 & 3.52 & 6.73 & 615.50 & 147.14 \\
\hline $\bar{x}$ & 0.99 & 1.95 & 2.40 & 4.39 & 455.97 & 108.97 & $2.63^{b}$ & $2.18^{b}$ & $3.12^{\mathrm{b}}$ & $5.93^{b}$ & $611.15^{b}$ & $145.99^{b}$ \\
\hline Sd & 0.14 & 0.06 & 0.18 & 0.28 & 44.61 & 10.69 & 0.40 & 0.17 & 0.27 & 0.53 & 43.27 & 10.45 \\
\hline cv (\%) & 14.14 & 3.28 & 7.26 & 6.38 & 9.78 & 9.81 & 15.21 & 7.80 & 8.65 & 8.94 & 7.08 & 7.16 \\
\hline
\end{tabular}

$\mathrm{S} / \mathrm{M}(\%)$-salt in moisture; EV-energetic value (KJ/100g); EV-energetic value (Kcal/100g); $\bar{x}_{\text {-arithmetic mean Sd-standard }}$ deviation; cv (\%)-coefficient of variation

${ }^{\mathrm{b}}$ Statistically significant difference $(\mathrm{p}<0.01)$ existed between Ricotta and the corresponding parameters obtained for Urda cheese 
Table 4. Classification of Urda and Ricotta samples according to fat on a dry matter basis and moisture on a fat-free basis content

\begin{tabular}{|c|c|c|c|c|c|c|c|c|c|c|}
\hline \multirow{2}{*}{ Samples } & \multicolumn{5}{|c|}{ URDA } & \multicolumn{5}{|c|}{ RICOTTA } \\
\hline & FDM & DMWF & MFFB & $\mathrm{C}-1$ & $\mathrm{C}-2$ & FDM & DMFW & MFFB & C-1 & $\mathrm{C}-2$ \\
\hline 1 & 27.47 & 13.20 & 86.10 & semi fat & soft & 14.69 & 24.67 & 74.23 & low fat & soft \\
\hline 2 & 27.37 & 15.92 & 83.06 & semi fat & soft & 17.63 & 25.37 & 73.17 & low fat & soft \\
\hline 3 & 22.77 & 15.26 & 84.02 & low fat & soft & 19.47 & 21.75 & 77.04 & low fat & soft \\
\hline 4 & 32.34 & 14.64 & 84.26 & semi fat & soft & 21.72 & 24.26 & 73.99 & low fat & soft \\
\hline 5 & 32.15 & 14.79 & 83.10 & semi fat & soft & 24.38 & 22.14 & 76.16 & low fat & soft \\
\hline 6 & 33.44 & 12.94 & 86.16 & semi fat & soft & 23.81 & 24.00 & 74.05 & low fat & soft \\
\hline 7 & 28.37 & 15.15 & 83.88 & semi fat & soft & 22.98 & 24.27 & 73.84 & low fat & soft \\
\hline 8 & 25.96 & 15.69 & 83.40 & semi fat & soft & 20.28 & 25.55 & 72.67 & low fat & soft \\
\hline 9 & 25.29 & 13.29 & 86.08 & semi fat & soft & 22.49 & 25.22 & 72.79 & low fat & soft \\
\hline 10 & 21.57 & 14.54 & 84.85 & low fat & soft & 21.68 & 23.62 & 74.73 & low fat & soft \\
\hline 11 & 26.99 & 14.88 & 84.25 & semi fat & soft & 23.65 & 24.47 & 73.52 & low fat & soft \\
\hline 12 & 26.87 & 13.61 & 85.67 & semi fat & soft & 17.35 & 24.30 & 74.39 & low fat & soft \\
\hline 13 & 29.52 & 15.52 & 83.40 & semi fat & soft & 21.92 & 23.30 & 75.07 & low fat & soft \\
\hline 14 & 24.31 & 15.57 & 83.61 & low fat & soft & 19.04 & 22.32 & 76.44 & low fat & soft \\
\hline 15 & 28.03 & 16.69 & 82.15 & semi fat & soft & 24.19 & 22.03 & 76.30 & low fat & soft \\
\hline $\bar{x}$ & 27.50 & 14.78 & 84.27 & & & $21.02^{b}$ & $23.82^{b}$ & $74.56^{b}$ & & \\
\hline Sd & 3.28 & 1.06 & 1.21 & & & 2.78 & 1.21 & 1.33 & & \\
\hline cv $(\%)$ & 11.93 & 7.17 & 1.44 & & & 13.22 & 5.08 & 1.78 & & \\
\hline
\end{tabular}

FDM-Fat on a dry matter basis; DMWF-Free fat dry matter; MFFB-Moisture on a fat-free basis; $\bar{x}$-arithmetic mean; Sd-standard deviation; cv (\%)-coefficient of variation; C-1: Classification according to FDM of cheese according to the Serbian Regulations (26); C-2: Classification according to MFFB according to the Serbian Regulations (26)

${ }^{\mathrm{b}}$ Statistically significant difference $(\mathrm{p}<0.01)$ existed between Ricotta and the corresponding parameters obtained for Urda cheese

Table 5. The amino acid composition of Urda and Ricotta $(\mathrm{g} / 100 \mathrm{~g})$

\begin{tabular}{|c|c|c|c|c|c|c|c|}
\hline \multicolumn{4}{|c|}{ URDA } & \multicolumn{4}{|c|}{ RICOTTA } \\
\hline $\begin{array}{l}\text { Essential } \\
\text { amino acid }\end{array}$ & $\bar{x}$ & Sd & cv $(\%)$ & $\begin{array}{l}\text { Essential } \\
\text { amino acid }\end{array}$ & $\bar{x}$ & Sd & cv (\%) \\
\hline Histidine & nd & - & - & Histidine & 0.13 & 0.008 & 6.15 \\
\hline Threonine & 0.68 & 0.009 & 1.32 & Threonine & $0.77^{\mathrm{a}}$ & 0.012 & 1.56 \\
\hline Valine & 0.26 & 0.023 & 8.85 & Valine & $0.50^{\mathrm{b}}$ & 0.046 & 9.2 \\
\hline Methionine & 0.12 & 0.005 & 4.17 & Methionine & $0.36^{\mathrm{a}}$ & 0.021 & 5.83 \\
\hline Phenylalanine & 0.31 & 0.038 & 12.26 & Phenylalanine & $0.78^{\mathrm{a}}$ & 0.061 & 7.82 \\
\hline Isoleucine & 0.23 & 0.021 & 9.13 & Isoleucine & $0.33^{\mathrm{b}}$ & 0.034 & 10.30 \\
\hline Leucine & 0.80 & 0.045 & 5.62 & Leucine & $1.60^{\mathrm{b}}$ & 0.046 & 2.87 \\
\hline Lysine & 0.45 & 0.055 & 12.22 & Lysine & $1.17^{\mathrm{b}}$ & 0.056 & 4.79 \\
\hline $\begin{array}{l}\text { Non-essential } \\
\text { amino acid }\end{array}$ & $\bar{x}$ & Sd & $\operatorname{cv}(\%)$ & $\begin{array}{l}\text { Non-essential } \\
\text { amino acid }\end{array}$ & $\bar{x}$ & Sd & cv (\%) \\
\hline Asparatic acid & 0.80 & 0.048 & 6.00 & Asparatic acid & $1.68^{\mathrm{b}}$ & 0.085 & 5.06 \\
\hline Glutamic acid & 1.65 & 0.065 & 3.94 & Glutamic acid & $3.91^{\mathrm{b}}$ & 0.091 & 2.33 \\
\hline Serine & 0.47 & 0.020 & 4.25 & Serine & $1.09^{\mathrm{b}}$ & 0.035 & 3.21 \\
\hline Glycine & 0.14 & 0.011 & 7.86 & Glycine & $0.33^{\mathrm{b}}$ & 0.057 & 17.27 \\
\hline Arginine & 0.16 & 0.017 & 10.62 & Arginine & $0.41^{\mathrm{b}}$ & 0.012 & 2.93 \\
\hline Alanine & 0.37 & 0.021 & 5.67 & Alanine & $0.74^{\mathrm{b}}$ & 0.021 & 2.84 \\
\hline Tyrosine & 0.22 & 0.012 & 5.45 & Tyrosine & $0.65^{\mathrm{b}}$ & 0.033 & 5.08 \\
\hline
\end{tabular}

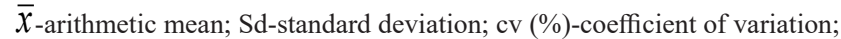

${ }^{a}$ Statistically significant difference $(\mathrm{p}<0.05)$ existed between Ricotta and the corresponding parameters obtained for Urda cheese;

${ }^{\mathrm{b}}$ Statistically significant difference $(\mathrm{p}<0.01)$ existed between Ricotta and the corresponding parameters obtained for Urda cheese 
The obtained values of FDM, DMWF and MFFB are presented in Table 4. The average values of MFFB and FDM were higher in Urda cheese, while Ricotta possessed a higher level of DMWF, but a smaller coefficient of variation (cv: 5.08\% and $7.17 \%$, respectively). According to the criterion of Serbian Regulations (26) and based on FDM content, twelve examined samples of Urda belonged to semi-fat and only three to low-fat cheeses. On the other hand, all examined samples of Ricotta cheeses belonged to the group of low-fat cheeses. In addition, based on MFFB content all samples belonged to the group of soft cheeses.

\section{Amino acids profile}

Table 5. showed the results of amino acids composition for the examined cheeses. In Ricotta cheese, the leucine was the major essential amino acid, followed by lysine, phenylalanine and threonine. Urda cheese was also more abundant in leucine, threonine, lysine and phenylalanine, while histidine was not observed. Means for non-essential amino acids indicated that glutamic acid was present at a high concentration (Ricotta, 3.91g/100g, $v s$. Urda, $1.65 \mathrm{~g} / 100 \mathrm{~g}$, respectively). The results also demonstrated that the essential amino acids of Urda and Ricotta cheese represented more than one-third of the total amino acids in whey cheese proteins (42.80\% vs. 39.03\%, respectively). Furthermore, if we observe the amino acids with branched chain (BCAAs), they accounted for $45.26 \%$ and $43.09 \%$ of the total content of essential amino acids, in Urda and Ricotta samples, respectively.

\section{DISCUSSION}

The quality and nutritional value of cheese is defined by its composition (1). As a standard, Ricotta is made from sweet whey because high acidification destabilizes whey proteins and in the production of this cheese usually whey with $\mathrm{pH}$ values above 6.2 is used (27). In our research, whey used in the production of Urda and Ricotta possessed higher $\mathrm{pH}$ value that ranged from a minimum of 6.30 up to 6.53 . The $\mathrm{pH}$ values were monitored during the production process and coefficients of variation showed small variations between different batches. Such results indicate that the production process had been harmonized in terms of these parameters and the addition of milk did not have a significant influence $(\mathrm{p}<0.05$, $\mathrm{p}<0.01$ ). There are several studies reporting that the shelf life of Ricotta is limited (even under refrigeration) because of high moisture content and its initial $\mathrm{pH}$ above $6.0(3,7)$. Therefore, the results of Alichanidis and Polychroniadou (20) showed that most fresh whey cheeses measured a moisture content of $65-70 \%$ with $\mathrm{pH}$ values of 5.5-6.0. Our results for Urda cheese differed, as the approximate moisture amounted to $79.59 \%$, whereas Ricotta was within this range. These values characterize them as high-moisture cheese (26). It is also known that a high value of moisture and $\mathrm{pH}$ with a low salt level contributes to the physicochemical and sensory properties of cheese and could lead to flavour and textural defects (1). It should also be noted that different whey cheeses possessed different $\mathrm{pH}$ values of final products. Vrdoljak et al. (28) reported the $\mathrm{pH}$ value of whey cheese (skuta) was in a range from 6.06 to 6.42 , whereas creamy Ricotta showed a higher initial pH (6.77) (29). Compared with this, the whey-based Ricotta obtained from sheep milk measured a pH value of 6.54 (30). The level of salt in cheese is very important because it contributes to cheese flavour, control of microbial growth, enzyme activity and acts as a natural preservative. Also, it significantly contributes to the nutritional value of the cheese. The concentration (\%) of salt in cheeses ranges from 0.7 in Swiss cheese to 6 for Domiati cheese (6). Salt concentration seemed to have the strongest influence on cheese quality and the lowest percentage of downgraded cheeses can be expected in the salt range $1.6-1.8 \%(\mathrm{~S} / \mathrm{M}$ : 4.0-4.9\%) (1). Obtained values for our cheeses are lower than those mentioned in the relation of salt in moisture content, but higher in relation to the percentage of salt in the cheese (S/M: $2.48 \%$ vs. $3.12 \%$, and $1.95 \%$ vs $2.18 \%$, Urda and Ricotta, respectively). Most dietary guidelines worldwide recommend moderate salt intake and there has been considerable interest in the production of reducedsodium cheeses (1).

Production of good quality low-fat whey cheese is particularly challenging, because even small variations in the cheese-making process can result in cheeses with a different composition. The amount of various nutrients retained in the curd largely depends on the type of cheese being manufactured, the type of whey used and the method of coagulation. Because of the large natural variation of whey, it is unlikely that cheeses made of whey will have exactly the same composition. According to Codex regulations, whey cheese must not exceed $33 \%$ of FDM and must contain minimum $10 \%$ of FDM (31) and our results were in conformity with these values (FDM, 27.50\% vs. $21.02 \%$, Urda and Ricotta, respectively). Often, in order to improve 
the cheese (compositional) quality and production yield a certain percentage of milk, cream, salt, citric acid or acetic acid is added to the whey. As a result of this, the different Ricotta brands retain yield which ranges from to $6 \%$ (32), while the yield of Urda cheeses varied from $2.11 \%$ to $5.32 \%$ (5). Results in our study confirmed that whey cheeses are not high-yield cheeses (approximate: Urda, $4.39 \%$ vs. Ricotta, 5.93\%, respectively). Findings of a large study indicated that there is no uniform chemical composition of these products and results in terms of the chemical composition of Ricotta are very diverse. Souza et al. (33) evaluated 30 samples of Ricotta and found that $16.67 \%$ of the samples could be classified as low-fat cheese, $23.33 \%$ as semi-fat cheese and $60 \%$ as full-fat cheese. In the chemical composition of Ricotta cheese produced in laboratory conditions water was dominant (72.89\%), while protein, fat and ash were amounted by only $0.6 \%, 0.7 \%$, and $6.9 \%$, respectively (34). Examining artisanal and industrial Ricotta samples Mattera et al. (35) noticed that industrial Ricotta showed a greater homogeneity in view of their chemical composition. Lack of uniformity with greater coefficients of variation found for fat (48.35\%) and protein (23.61\%) was determined in a research done by Madalozzo et al. (36). Casti et al. (30) indicated the role of raw material quality and contrary to our results they obtained higher values for total solids $(42.12 \%)$, fat $(19.55 \%)$, protein $(14.84 \%)$ and salt $(3.42 \%)$ for Ricotta produced from whey from sheep milk cheeses. Similarly, traditional Urda in the study by Bojanic-Rasovic et al. (37) was substantially different in average chemical composition from our results for Urda. In particular, they showed higher mean values of dry matter $(42.85 \%)$, fat $(21.74 \%)$, protein $(13.66 \%)$, and salt content $(2.67 \%)$. Our results also differed from results previously published by Pappa et al. (38) concerning traditional made Urda cheese from sheep and goat whey (protein: $14.57 \%$ and $12.63 \%$, respectively, and fat: $28.50 \%$ and $29.70 \%$, respectively), but were in similarity with the findings of Alichanidis and Polychroniadou (20) with regard to protein and lactose content in fresh Urda cheese (9-14\% and 3.5-4.5\%, respectively).

Total fat content and total energy are the most important factors for human health when choosing a cheese. Consumer demand for low-fat calorie products has significantly increased in recent years. According to this study, low-fat cheeses are a good way of reducing energy in the diet. Fox et al. (1) reported that Ricotta cheese contains $144 \mathrm{kcal} / 599 \mathrm{~kJ}$ of energy value, which is similar to our results. Generally, cheeses are considered as a protein concentrate, but whey cheeses have a high content of preferred amino acids for human nutrition. In fact, whey cheeses, such as Ricotta and Urda, can make a significant contribution to the recommended intake for proteins which are characterized by their easy assimilation. Ricotta, as acid coagulated cheeses treated with high temperature, contains all three milk proteins (casein, lactoglobulin and lactoalbumin) in appreciable amounts. In general, cheese provides all essential amino acids except methionine and cysteine in more than the recommended quantities for children or adults (39). Each amino acid has a specific role and Wolfe (40) stated that dietary proteins in cheese are rich in essential amino acids and amino acids with branched-chain (BCAAs), in particular, leucine provides health benefits that typically are not observed in a meal containing proteins from other sources. Thus, BCAAs are important precursors of tricarboxylic acid (TCA) cycle intermediates via acetyl-CoA and succinyl-CoA and they are necessary for muscle cells to promote protein synthesis (41). Our presented results are corroborated by the findings of Borba (29), where major essential amino acids were leucine, followed by lysine and threonine and means for non-essential amino acids indicated that glutamic acid was present in at higher concentrations. Similar results were published by Mohamed et al. (42). However, little research has been conducted to describe the amino acids content of Urda cheese made from bovine whey. Bilyk (43) investigated traditional Urda made from sheep and mixed sheep and bovine whey, and their results as expected showed higher amino acids content for all investigated amino acids, but the major essential amino acids were the same (leucine, lysine and threonine). Slightly different results for Bračka skuta cheese made from sheep whey were published by Rako et al. (44), where prevailing amino acids were leucine, phenylalanine and isoleucine. Furthermore, an amino acid composition for Ricotta originating from cow's and sheep's whey was similar and protein quality was good (chemical score 91 for sheep and 89 for cow milk Ricotta samples) in both Ricotta types (35).

\section{CONCLUSION}

The results observed by the Ricotta chemical composition showed a considerable difference from Urda cheese samples. Milk addition seemed to have the strongest influence on cheese quality 
and therefore significantly affected Ricotta composition and quality. Ricotta contained higher levels of dry matter, fat, protein, ash, and salt, while Urda possessed higher values for fat on a dry matter basis and moisture on a dry matter basis. The results also confirm that Ricotta belongs to the group of low-fat cheese and Urda to the groups of low and semi-fat cheeses. However, despite standardizing procedure in cheese manufacture, whey cheese composition still widely varied, thus confirming the difficulties in producing whey cheese of uniform quality. In particular, Urda varied more in protein and lactose content, while Ricotta showed more variations for yield and salt content. Contrary to this, the dynamics of change in $\mathrm{pH}$ values did not show large variations during the production of different batches. The two types of cheese also have different amino acid profiles and the content of investigated amino acids was significantly higher in Ricotta. On the other hand, both types of cheese contained a high content of essential amino acids. Obtained results on the amino acid composition of investigated whey cheeses represent valuable information about their protein quality and could contribute, as well, to the nutrition and health research. This further confirms that whey cheeses will gain more importance as nutritious food once their nutritional attributes have been standardized and consistent.

\section{CONFLICT OF INTEREST}

The authors declared that they have no potential conflict of interest with respect to the authorship and/or publication of this article.

\section{ACKNOWLEDGEMENTS}

This study was partly supported by the Ministry of Education, Science and Technological Development of the Republic of Serbia, Project No. TR31085.

\section{REFERENCES}

1. Fox, F.P., Guinee, P.T., Cogan, M.T., McSweeney, L.H.P. (2000). Fundamentals of cheese science (pp. 504-513). Gaithersburg, Maryland: Aspen Publishers Inc.
2. Ko, S., Kwak, H.S. (2009). Bioactive components in whey products. In: Park, Y.W., (Ed.), Bioactive components in milk and dairy products (pp. 263-284). Ames, IA, USA: Wiley-Blackwell.

https://doi.org/10.1002/9780813821504.ch11

PMid:19132382

3. Pintado, M.E., Macedo, A.C., Malcata, F.X. (2001). Review: Technology, chemistry and microbiology of whey cheeses. Food Science Technology International 7 (2):105-116.

https://doi.org/10.1177/108201301772660277

4. Addeo, F., Masi, P. (1992). Production of pasta cheese. Cogan T.M. (Ed.), $3^{\text {rd }}$ cheese symposium, National Dairy Products Research Center. Moorepark, (pp. 31-40). Teagasc, Fermoy, Co. Cork. Ireland

5. Popović Vranješ, A. (2015). Special cheesemaking (pp. 115-401). The University of Novi Sad, Faculty of Agriculture, Department of Animal Science, Indjija: Komazec press. [in Serbian]

6. Fox, F.P., McSweeney, L.H.P., Cogan, M.T., Guinee, P.T. (2004). Cheese: chemistry, physics and microbiology. General aspects. $3^{\text {rd }}$ Edition (pp. 978-981). Amsterdam: Elsevier Applied Science.

7. Davies, E.A., Bevis, H.E., Delves Broughton, J. (1997). The use of the bacteriocin, nisin, as a preservative in ricotta-type cheeses to control the food-borne pathogen Listeria monocytogenes. Letters in Applied Microbiology 24, 343-346. https://doi.org/10.1046/j.1472-765X.1997.00145.x PMid:9172439

8. El Sheikh, M., Farrag, A., Zaghloul, A. (2010). Ricotta cheese from whey protein concentrate. Journal of American Sci. 6 (8):321-325.

9. Bilyk, O., Slyvka, N., Gutyj, B., Dronyk, H., Sukhorska, O. (2017). Study of the different ways of proteins extraction from sheep and cow whey for Urda cheese production. Reports on research projects. Eureka: Life Sciences, Food Science and Technology. Number 3.

https://doi.org/10.21303/2504-5695.2017.00333

10. Dozet, N.D., Maćej, O.D., Jovanović, S.T. (2004). Indigenous dairy products as the basis for the development of specific original dairy products in modern conditions. Biotech. in Animal Husbandry $20(3-4): 31-48$.

https://doi.org/10.2298/BAH0404031D

11. Kaminarides, S., Ilias Dimopoulos, E., Zoidou, E., Moatsou, G. (2015). The effect of the addition of skimmed milk on the characteristics of Myzithra cheeses. Food Chemistry 180, 164-170. https://doi.org/10.1016/j.foodchem.2015.01.086 PMid:25766814 
12. Antunac, N., Hudik, S., Mikulec, N., Maletić, M., Horvat, I., Radeljević, B., Havranek, J. (2011). Production and chemical composition of Istria and Pag whey cheese. Mljekarstvo 61 (4):326-335.

13. Yasmin, A., Butt, S.M., Sameen, A., Shahid, M. (2013). Physicochemical and Amino Acid Profiling of Cheese Whey. Pakistan Journal of Nutrition 12 (5):455-459.

https://doi.org/10.3923/pjn.2013.455.459

14. Etzel, R.M. (2004). Manufacture and use of dairy protein fractions. The Journal of Nutrition 134 (4): 996-1002.

https://doi.org/10.1093/jn/134.4.996S

PMid:15051860

15. Tratnik, Lj. (2003). The role of whey in the production of functional dairy foods. Mljekarstvo 53 (4):325-352.

16. Rozenberg, S., Body, J.J., Bruyere1, O., Bergmann, P., Brandi, M.L., Cooper, C., Devo-Gelaer, J.P., Gielen, E., Goemaerel, S., Kaufman, J.M., Rizzoli, R., Reginster, J.Y. (2016). Effects of dairy products consumption on health: benefits and beliefs-a commentary from the Belgian bone club and the European society for clinical and economic aspects of osteoporosis, osteoarthritis and musculoskeletal diseases. Calcif Tissue Int. 98, 1-17.

https://doi.org/10.1007/s00223-015-0062-x

PMid:26445771 PMCid:PMC4703621

17. Cho, E., Smith Warner, S.A., Spiegelman, D., Beeson, W.L., Van den Brandt, P.A., Colditz, G.A., Folsom, A.R., Fraser. G.E., Freudenheim, J.L., Giovannuci, E. (2004). Dairy foods, calcium, and colorectal cancer: a pooled analysis of 10 cohort studies. Journal of National Cancer Institute 96, 1015-1022.

https://doi.org/10.1093/jnci/djh185

PMid:15240785

18. Davoodi, H., Esmaeili, S., Mortazavian, A.M. (2013). Effects of milk and milk products consumption on cancer: A Review. Comprehensive Reviews in Food Science and Food Safety 12, 249-264. https://doi.org/10.1111/1541-4337.12011

19. Mateo, A.H., Macías, L., Romero, E.J., García, A.H., Blancas, L.A. (2012). Physiological effects beyond the significant gain in muscle mass in sarcopenic elderly men: evidence from a randomized clinical trial using a protein-rich food. Clinical Interventions in Aging (Albany NY) 7, 225-234.

https://doi.org/10.2147/CIA.S32356

PMid:22866000 PMCid:PMC3410682

20. Alichanidis, E., Polychroniadou, A. (2008). Characteristics of major traditional regional cheese varieties of East-Mediterranean countries: a review. Dairy Science Technology 88, 495-510. https://doi.org/10.1051/dst:2008023
21. AOAC (1995). Official Methods of Analysis of the AOAC, 16th ed. Methods 968.30, 978.18, 945.68, 981.12, Association of official analytical chemists, Arlington, VA, USA.

22. AOAC (2005). Official Methods of Analysis of the AOAC, 17th ed Vol. II, 33: Methods 926.08, 2000.18, 933.05, 2001.14, 935.42, 920.124, AOAC International, Gaithersburg, MD.

23. IDF (2008). International IDF Standard 222:2008 (Cheese and processed cheese products. Determination of Fat Content-Van Gulik method), IDF, Brussels, Belgium.

24. AOAC (1998). Official Methods of Analysis, 16th ed., 4th Revision. Methods 896.01, 984.15, 930.28, 972.16, AOAC International, Gaithersburg, MD.

25. Henderson, W.J., Ricker, D.R., Bidlingmeyer, A.B., Woodward, C. (2000). Rapid, accurate, sensitive, and reproducible HPLC analysis of amino acid analysis using Zorbax Eclipse-AAA Columns and the Agilent 1100 HPLC. Agilent Technologies. PN 5980-1193E.

26. Serbian Regulation (2014). Ordinance on the quality of dairy products and starter cultures. Official Gazette of the Republic of Serbia, No. $34 / 2014$.

27. Chandan, R.C., Kilara, A. (2011). Dairy ingredients for food processing (pp. 179-199). Ames, IA: Willey Blackwell.

https://doi.org/10.1002/9780470959169

28. Vrdoljak, J., Dobranić, V., Filipović, I., Zdolec, N. (2016). Microbiological quality of soft, semi-hard and hard cheeses during the shelf-life. Mac Vet Rev. 39 (1):59-64.

https://doi.org/10.1515/macvetrev-2015-0068

29. Borba, K.K.S. (2013). Development and characterization of creamy ricotta cheese made with rennet goat and bovine [dissertation]. Federal University of Paraiba, Campus I, Joao Pessoa, Paraiba.

30. Casti, D., Scarano, C., Pala, C., Cossu, F., Lamon, S., Spanu, V., Ibba, M., Mocci, A.M., Tedde, F., Nieddu, G., Spanu, S., De Santis, L.P.E. (2016). Evolution of the microbiological profile of vacuum-packed ricotta salata cheese during shelf-life. Italian Journal of Food Safety 5 (2): 57-60. https://doi.org/10.4081/ijfs.2016.5501

31. WHO/FAO (2011) [Internet]. Codex Alimentarius. Milk and milk products. Second Edition. World Health Organization/ Food and Agriculture Organization of UN, Rome 83-85. http://www.fao.org/3/i2085e/i2085e00.pdf 
32. Ribeiro, A.C., Marques, S.C., Sodré, A.F., Abreu, L.R., Piccoli, R.H. (2005). Microbiological assessment of creamy ricotta during shelf-life. Science and Agrotechnology 29 (1):113-117. https://doi.org/10.1590/S1413-70542005000100014

33. Souza, M.R., Morais, C.F.A., Corrêa, C.E.S., Rodrigues, R. (2000). Physicochemical characteristics of ricotta commercialized in Belo Horizonte. MG. Rev Hig Aliment. 14, 68-71.

34. Sulieman, A.M.E., Aisha S., Eljack, A.S., Zakaria, A., Salih, Z.A. (2012). Quality evaluation of "Ricotta" cheese produced at laboratory level. International Journal of Food Science and Nutrition Engineering 2 (6):108-112.

https://doi.org/10.5923/j.food.20120206.02

35. Mattera, M., Aguzzi, A. Nicoli, S. Cappelloni, M., Lucarini, M., Squasi, M.C., Marletta, L. (1999). Ewe and cow ricotta. An updating on nutrient composition. National Institute of Nutrition, Rome, Italy. [www.agris.fao.org/agris-search/search.do?recordID]

36. Madalozzo, E.S., Sauer, E., Nagata, N. (2015). Determination of fat, protein and moisture in Ricotta cheese by near-infrared spectroscopy and multivariate calibration. Journal of Food Sci. and Tec. 52 (3):1649-1655. https://doi.org/10.1007/s13197-013-1147-z PMid:25745236 PMCid:PMC4348305

37. Bojanic Rasovic, M., Nikolić, N., Rasovic, R. (2017). Quality of "Urda" obtained after production of Montenegrin semi-hard cheese. Food Research 1 (5):166-170. https://doi.org/10.26656/fr.2017.5.107

38. Pappa, C.E., Samelis, J., Kondyli, E., Pappas, A. (2016). Characterisation of Urda whey cheese: Evolution of main biochemical and microbiological parameters during ripening and vacuum packaged cold storage. International Dairy Journal 58, 54-57. https://doi.org/10.1016/j.idairyj.2015.12.016
39. Tomé, D., Bos, C., Mariotti, F., Gaudichon, C. (2002). Protein quality and FAO/WHO recommendations. Food Sci. 22, 393-405.

https://doi.org/10.3166/sda.22.393-405

40. Wolfe, R.R. (2002). Regulation of muscle protein by amino acids. Journal of Nutrition 132, 3219-3224. https://doi.org/10.1093/jn/131.10.3219S PMid:12368421

41. Valerio, A., D'Antona, G., Nisoli, E. (2011). Branched-chain amino acids, mitochondrial biogenesis, and healthspan: An evolutionary perspective. Aging (Albany NY) 3, 464-478.

https://doi.org/10.18632/aging.100322 PMid:21566257 PMCid:PMC3156598

42. Mohamed, S.A., Hasan, S.M., Abusalloum, S.T. (2014). Chemical characteristics of Italian Ricotta cheese as influenced by the proteolysis during ripening. Food Science and Technology Department, Fac. Mansoura Univ. 5 (2):45-53.

43. Bilyk, O. (2011). Technological ensuring of production, processing of products of animal origin and their preservation. Scientific Messenger of LNU Veterinary Medicine and Biotechnologies 2 (48): $317-321$.

44. Rako, A., Tudor Kalit, M., Kalit, S., Soldo, B., Ljubenkov, I. (2018). Nutritional characteristics of Croatian whey cheese (Bračka skuta) produced in different stages of lactation. LWT-Food Science and Tec. 96, 657-662.

https://doi.org/10.1016/j.1wt.2018.06.024 